\title{
Highly Practical and Enantioselective Cu-Catalyzed Conjugate Addition of Alkylzinc Reagents to Cyclic Enones at Ambient Temperature
}

\author{
Isaac J. Krauss and James L. Leighton* \\ Department of Chemistry, Columbia University, New York, New York, 10027 \\ Supporting Information
}

General Information. All reactions were carried out under an atmosphere of nitrogen in flame- or ovendried glassware with magnetic stirring unless otherwise indicated. All reaction solvents were purified by degassing with argon and passage through an activated alumina column. Copper (II) triflate, diphenylphosphine, (S)-tert-leucinol, and triflic anhydride and enones were obtained from Aldrich and used without further purification. Triethylamine was distilled from $\mathrm{CaH}_{2}$ prior to use. Diethylzinc was obtained from Strem, and diisopropylzinc and dibutylzinc were made by known methods. ${ }^{1}{ }^{1} \mathrm{H}$ NMR spectra were recorded on a Bruker DPX-300 (300 MHz) or a DPX-500 (500 MHz) spectrometer and are reported in $\mathrm{ppm}$ from $\mathrm{CDCl}_{3}$ internal standard $(7.26 \mathrm{ppm})$. Data are reported as follows: $(\mathrm{s}=$ singlet, $\mathrm{d}=$ doublet, $\mathrm{t}=$ triplet, $\mathrm{q}=$ quartet, quint $=$ quintet, $\mathrm{m}=$ multiplet, $\mathrm{dt}=$ doublet of triplets, $\mathrm{dd}=$ doublet of doublets, ddd = doublet of doublet of doublets; coupling constant(s) in Hz; integration; assignment). Proton decoupled ${ }^{13} \mathrm{C}$ NMR spectra were recorded on a Bruker DPX-300 (75 MHz) and are reported in ppm from $\mathrm{CDCl}_{3}$ internal standard $(77.0 \mathrm{ppm}) .{ }^{31} \mathrm{P}$ NMR spectra were reported on a Bruker DPX-300 (121.6 MHz) and are reported in ppm from $\mathrm{H}_{3} \mathrm{PO}_{4}\left(85 \%\right.$ in $\left.\mathrm{H}_{2} \mathrm{O}\right)$ external standard $(0.0 \mathrm{ppm}) .{ }^{19} \mathrm{~F}$ NMR spectra were recorded on a Bruker DPX-300 (282 MHz) and are reported in ppm from $\mathrm{CF}_{3} \mathrm{Cl}$ internal standard (0.0ppm). Infrared spectra were recorded on a Perkin Elmer Paragon 1000 FT-IR spectrometer. Gas chromatographic analyses were performed on a Hewlett-Packard 6890 Series Gas Chromatograph equipped with a capillary split-splitless inlet and flame ionization detector with electronic pneumatics control using either a Supelco ß-Dex 120 (30 m x 0.25 mm) capillary GLC column or an Astec Chiraldex

(1) Knochel, P.; Singer, R. Chem. Rev. 1993, 93, 2117-2188 and references cited therein. 
G-TA (30 m x $0.25 \mathrm{~mm}$ x $0.125 \mu \mathrm{m})$ capillary GLC column with Astec Retention Gap Guard Column (5m $\mathrm{x} 0.25 \mathrm{~mm})$. Optical rotations were recorded on a JASCO DIP-1000 digital polarimeter and the concentration $c$ is reported in $\mathrm{g} / 100 \mathrm{~mL}$. Low resolution mass spectra were obtained on a JEOL HX110 mass spectrometer in the Columbia University Mass Spectrometry Laboratory.

Preparation of ligand 2e: To a cooled $\left(-78^{\circ} \mathrm{C}\right)$ solution of $(S)$-tert-leucinol $(591 \mathrm{mg}, 5.04 \mathrm{mmol})$ and triethylamine $(1.40 \mathrm{~mL}, 10.1 \mathrm{mmol})$ in $\mathrm{CH}_{2} \mathrm{Cl}_{2}(20 \mathrm{~mL})$ was added triflic anhydride $(1.87 \mathrm{~mL}, 11.1 \mathrm{mmol})$ in $0.1 \mathrm{~mL}$ portions every three minutes (over 1 hour). After the addition was complete the solution was stirred for $1 \mathrm{~h}$, and then allowed to warm to $-50{ }^{\circ} \mathrm{C}$. After $14 \mathrm{~h}$ (Note: If the reaction is allowed to stir for prolonged periods at temperatures above $-50^{\circ} \mathrm{C}$, an impurity develops. Careful control of the reaction temperature is necessary to avoid this) the mixture was then poured into a separatory funnel containing 20 $\mathrm{mL}$ of chilled $\left(0^{\circ} \mathrm{C}\right) 0.1 \mathrm{M} \mathrm{HCl}$. The mixture was shaken and separated, and the organic phase was washed with an additional $20 \mathrm{~mL}$ of chilled $0.1 \mathrm{M} \mathrm{HCl}$. The organic phase was then washed with $2 \times 20$ $\mathrm{mL}$ of chilled $\left(0^{\circ} \mathrm{C}\right)$ saturated aqueous sodium carbonate. The organic phase was then dried over $\mathrm{MgSO}_{4}$, filtered and concentrated. The residue ( $991 \mathrm{mg}$ of aziridine 1e) was found to be $>95 \%$ pure as judged by ${ }^{1} \mathrm{H}$ NMR analysis, and was used directly in the next step.

To a cooled $\left(-78^{\circ} \mathrm{C}\right)$ solution of diphenylphosphine $(708 \mu \mathrm{L}, 4.07 \mathrm{mmol})$ in $\mathrm{THF}(20 \mathrm{~mL})$ was added $n$-BuLi (2.5M in Hexanes, $1.64 \mathrm{~mL}, 4.07 \mathrm{mmol})$. The solution was permitted to warm to $0{ }^{\circ} \mathrm{C}$ and was then recooled to $-78^{\circ} \mathrm{C}$. The aziridine $1 \mathrm{e}(991 \mathrm{mg}, 4.29 \mathrm{mmol})$ was added by cannula, with 3 x $3 \mathrm{~mL}$ THF rinse. After $15 \mathrm{~min}$ the solution was allowed slowly to warm to room temperature over the course of $2 \mathrm{~h}$. After addition of glacial acetic acid $(245 \mu \mathrm{L}, 4.29 \mathrm{mmol})$, the mixture was concentrated. The residue was treated with $\mathrm{CH}_{2} \mathrm{Cl}_{2}$ and the resulting mixture was filtered through a plug of silica gel. The filtrate was concentrated and the residue was recrystallized from hexanes (after hot filtration to remove insoluble material) to afford $1.17 \mathrm{~g}(56 \%$ overall $)$ of ligand $2 \mathrm{e}$ as a crystalline white solid. $[\square]_{\mathrm{D}}=+81.2^{\circ}(c 1.93$, $\mathrm{CH}_{2} \mathrm{Cl}_{2}$ ); ${ }^{1} \mathrm{H}$ NMR (300 MHz, $\mathrm{CDCl}_{3}$ ), $\square 7.52-7.42$ (m, 2H, ArH), 7.41-7.27 (m, 8H, ArH), 4.80 (br d, $J=$ $10.0 \mathrm{~Hz}, 1 \mathrm{H}, \mathrm{NH}), 3.36(\mathrm{~m}, 1 \mathrm{H}, t-\mathrm{Bu}-\mathrm{CH}), 2.56\left(\mathrm{~m}, 1 \mathrm{H}\right.$, one of $\left.\mathrm{PCH}_{2}\right), 2.08\left(\mathrm{~m}, 1 \mathrm{H}\right.$, one of P-CH $\mathbf{H}_{2}, 0.93$ (s, 9H, C(CH$\left.)_{3}\right) ;{ }^{13} \mathrm{C}$ NMR (75 $\left.\mathrm{MHz}, \mathrm{CDCl}_{3}\right) \square$ 138.4, 138.3, 137.1, 136.9, 133.7, 133.4, 132.4, 132.1, $129.3,128.7,128.6,128.5,128.5,121.5,117.2,63.0\left(\mathrm{~d}, J_{P C}=14.5 \mathrm{~Hz}\right), 35.8\left(\mathrm{~d}, J_{P C}=4.2 \mathrm{~Hz}\right), 32.6\left(\mathrm{~d}, J_{P C}\right.$ 
$=16.9 \mathrm{~Hz}), 26.5 ;{ }^{31} \mathrm{P} \mathrm{NMR}\left(121.6 \mathrm{MHz}, \mathrm{CDCl}_{3}\right) \square-23.8\left(\mathrm{q}, J_{P F}=15.2 \mathrm{~Hz}\right) ;{ }^{19} \mathrm{~F} \mathrm{NMR}\left(282 \mathrm{MHz}, \mathrm{CDCl}_{3}\right) \square$ $75.0\left(\mathrm{~d}, J_{P F}=15.0 \mathrm{~Hz}\right)$; IR (thin film) 3830 (br), 3053, 2967, 1480, 1436, 1367, 1195, 1141, 739, 697, 612 $\mathrm{cm}^{-1}$; LRMS (FAB+) calc'd 417.114, found 417.116.

Procedure for the reaction shown in Scheme 2: To a suspension of $38 \mathrm{mg}(.104 \mathrm{mmol})$ of $\mathrm{Cu}(\mathrm{OTf})_{2}$ and $109 \mathrm{mg}(.260 \mathrm{mmol})$ of ligand $\mathbf{2 e}$ in $150 \mathrm{~mL}$ of $\mathrm{CH}_{2} \mathrm{Cl}_{2}$ was added dropwise $13.1 \mathrm{~mL}(15.4 \mathrm{~g}, 125$ $\mathrm{mmol}$ ) of $\mathrm{Et}_{2} \mathrm{Zn}$. The suspension was stirred for $10 \mathrm{~min}$, and the reaction vessel was then immersed in an ambient temperature $\left(\sim 23{ }^{\circ} \mathrm{C}\right)$ water bath. 2-cyclohexen-1-one (10.1. $\left.\mathrm{mL}, 10.0 \mathrm{~g}, 104 \mathrm{mmol}\right)$ was added dropwise over approximately 2 min (NOTE: if the enone is added too rapidly, a mild exotherm ensues; we have found that the rate of addition and extent of exotherm have little effect on the yield and enantioselectivity of the reaction). As monitored by GC (Chiraldex G-TA column) the reaction was complete within $1.5 \mathrm{~h}$. The reaction mixture was cooled with an ice bath and the reaction was quenched by the dropwise at first addition of $1 \mathrm{M} \mathrm{HCl}(\mathrm{aq})$ (CAUTION! this quenching of excess $\mathrm{Et}_{2} \mathrm{Zn}$ must be carried out slowly to avoid a vigorous exotherm). After $300 \mathrm{~mL}$ of $1 \mathrm{M} \mathrm{HCl}$ had been added, the mixture was poured into a separatory funnel. The mixture was shaken, the layers were then separated and the aqueous phase was extracted with an additional 3 x $300 \mathrm{~mL} \mathrm{CH} \mathrm{Cl}_{2}$. The combined organic extracts were dried over $\mathrm{MgSO}_{4}$, filtered, and concentrated. The residue was purified by flash column chromatography on silica gel (19:1 Pentane:Et $2 \mathrm{O})$, to afford 11.3 grams (86\% yield, 97\% ee) of $(S)$-3-ethylcyclohexanone as a colorless oil.

General Procedure for Conjugate Addition: A $25 \mathrm{~mL}$ roundbottom flask is charged with $\mathrm{Cu}(\mathrm{OTf})_{2}$ $(7.2 \mathrm{mg}, .020 \mathrm{mmol})$, ligand $2 \mathrm{e}(20.8 \mathrm{mg}, .050 \mathrm{mmol})$ and $5 \mathrm{~mL} \mathrm{CH} \mathrm{Cl}_{2}$. The resulting suspension is stirred for $20 \mathrm{~min}$, after which time neat $\mathrm{R}_{2} \mathrm{Zn}(3.0 \mathrm{mmol})$ and enone $(1.0 \mathrm{mmol})$ are added, 10 minutes apart (see Table 2 for order of addition). After the reaction is complete as monitored by TLC, $1 \mathrm{M} \mathrm{HCl}$ (5 $\mathrm{ml}$ ) is added (dropwise at first!) and the mixture is extracted with $3 \times 10 \mathrm{~mL}$ of ether. The combined organics are dried over $\mathrm{MgSO}_{4}$, filtered and concentrated. The residue is purified by flash chromatography (19:1 ether:pentane) to give the products in the yields and enantioselectivities indicated in Table 2. 
Preparation of $(1 S, 5 S, 7 R)-5-E t h y l-8,8-d i m e t h y l-b i c y c l o[5.1 .0]$ octan-3-one (Scheme 3): The general procedure was employed (see above). $[\square]_{\mathrm{D}}=+107^{\circ}\left(c 1.24, \mathrm{CH}_{2} \mathrm{Cl}_{2}\right) ;{ }^{1} \mathrm{H} \mathrm{NMR}\left(500 \mathrm{MHz}, \mathrm{CDCl}_{3}\right)$ - $2.79\left(1 \mathrm{H}, \mathrm{dd}, J=11.5,5.0 \mathrm{~Hz}\right.$, one of $\left.\mathrm{C}(2) \mathbf{H}_{2} \mathrm{CO}\right), 2.53(1 \mathrm{H}, \mathrm{ddd}, J=14.3,7.0,1.6 \mathrm{~Hz}$, one of $\left.\mathrm{COC}(4) \mathbf{H}_{2}\right), 2.13\left(1 \mathrm{H}, \mathrm{dd}, J=14.3,10.2 \mathrm{~Hz}\right.$, one of $\left.\mathrm{COC}(4) \mathbf{H}_{2}\right), 2.07(1 \mathrm{H}, \mathrm{dd}, J=11.5,8.6 \mathrm{~Hz}$, one of $\left.\mathrm{C}(2) \mathbf{H}_{2} \mathrm{CO}\right), 2.04-1.95\left(1 \mathrm{H}, \mathrm{m}\right.$, one of $\left.\mathrm{C}(6) \mathbf{H}_{2}\right), 1.80-1.72\left(1 \mathrm{H}, \mathrm{m}\right.$, one of $\left.\mathrm{C}(6) \mathbf{H}_{2}\right), 1.33$ (2H, apparent quint, $\left.J=7.2 \mathrm{~Hz}, \mathrm{C}(5) \mathrm{HCH}_{2} \mathrm{CH}_{3}\right), 1.08\left(3 \mathrm{H}\right.$, s, one of $\left.\left(\mathrm{CH}_{3}\right)_{2} \mathrm{C}(8)\right), 1.06\left(3 \mathrm{H}\right.$, s, one of $\left.\left(\mathrm{CH}_{3}\right)_{2} \mathrm{C}(8)\right), 1.0$ $0.89\left(4 \mathrm{H}, \mathrm{m}, \mathrm{C}(5) \mathbf{H}\right.$ and $\left.\mathrm{C}(5) \mathrm{HCH}_{2} \mathrm{CH}_{3}\right), 0.80-0.65(2 \mathrm{H}, \mathrm{m}, \mathrm{C}(7) \mathbf{H}$ and $\mathrm{C}(1) \mathbf{H}) ;{ }^{13} \mathrm{C} \mathrm{NMR}(75 \mathrm{MHz}$, $\left.\mathrm{CDCl}_{3}\right) \square 212.5,50.3,39.6,39.5,30.0,28.9,26.8,21.7,20.5,15.5,12.0$; IR (neat) 2957, 2928, 2875, 1703, 1459, 1378, 1288, 1165, $796 \mathrm{~cm}^{-1}$; LRMS (APCI, M+H) calc'd 181.30, found 181.06.

\section{Stereochemical determinations and proofs:}

Proof of the cis relative configuration for $(1 S, 5 S, 7 R)$-5-Ethyl-8,8-dimethyl-bicyclo[5.1.0]octan-3-one was provided by the illustrated nOe experiment (Figure 1).

Figure 1. Key nOe interaction observed to establish cis relative configuration.

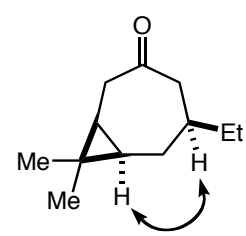

3-(S)-(2'-Methylethyl)-cyclopentanone (Table 2, entry 1): Astec Chiraldex G-TA (30m x 0.25mm x $0.125 \mu \mathrm{m})$ with Astec Retention Gap Guard Column $(5 \mathrm{~m} \times 0.25 \mathrm{~mm}), 1.0 \mathrm{~mL} / \mathrm{min} \mathrm{He}$ flow, $90{ }^{\circ} \mathrm{C}$. This is a known compound. ${ }^{2}$ The absolute configuration was assigned by analogy.

(2) Degrado, S. J.; Mizutani, H.; Hoveyda, A. H. J. Am. Chem. Soc. 2001, 123, 755-756. 

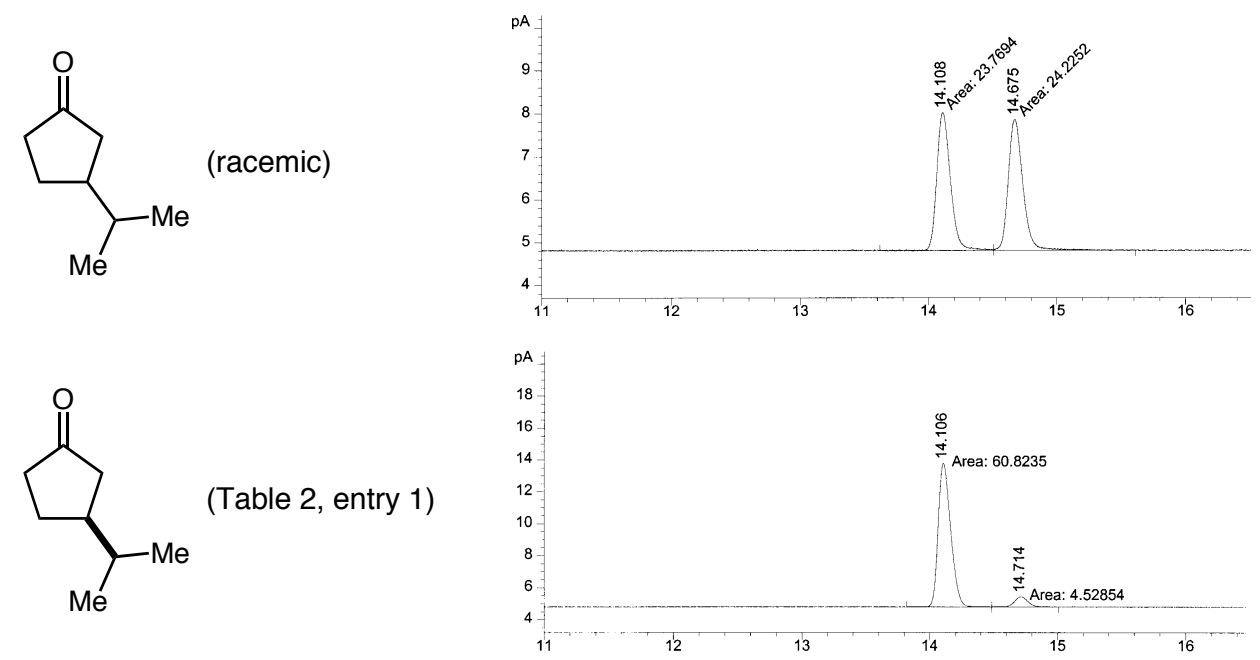

4-(R)-Ethyl-3,3-dimethylcyclopentanone (Table 2, entry 2): Astec Chiraldex G-TA (30m x 0.25mm x $0.125 \mu \mathrm{m})$ with Astec Retention Gap Guard Column $(5 \mathrm{~m}$ x $0.25 \mathrm{~mm}), 1.0 \mathrm{~mL} / \mathrm{min} \mathrm{He}$ flow, $100{ }^{\circ} \mathrm{C}$. This is a known compound and it has been established that the $S$ enantiomer has the shorter retention time. ${ }^{2}$

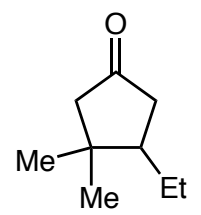

(racemic)
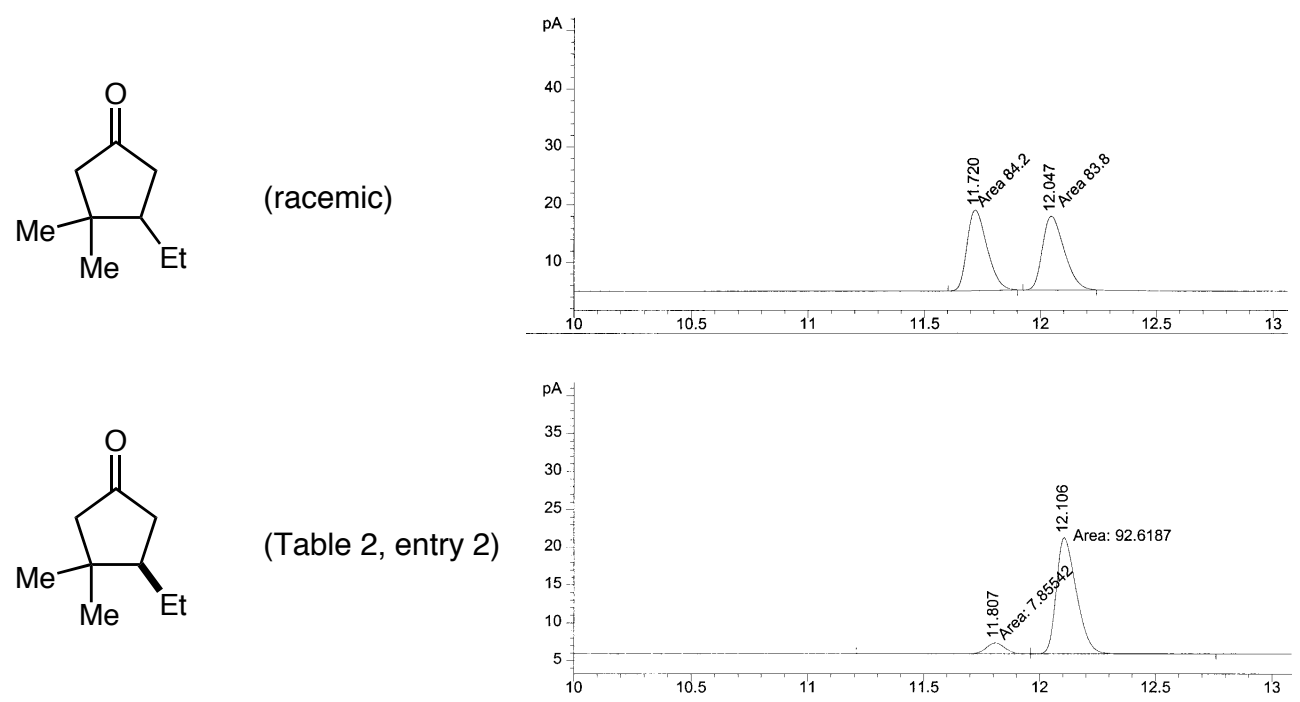

3-(S)-Ethylcyclohexanone (Table 2, entry 3): Astec Chiraldex G-TA (30m x 0.25mm x 0.125 $\mu \mathrm{m})$ with Astec Retention Gap Guard Column (5m x 0.25mm), $1.0 \mathrm{~mL} / \mathrm{min}$ He flow, $100{ }^{\circ} \mathrm{C}$. This is a known compound and it has been established that the $R$ enantiomer has the shorter retention time. ${ }^{2}$ 
<smiles>CCC1CCCC(=O)C1</smiles>

(racemic)<smiles>CCC1CCCC(=O)C1</smiles>

(Table 2, entry 3)
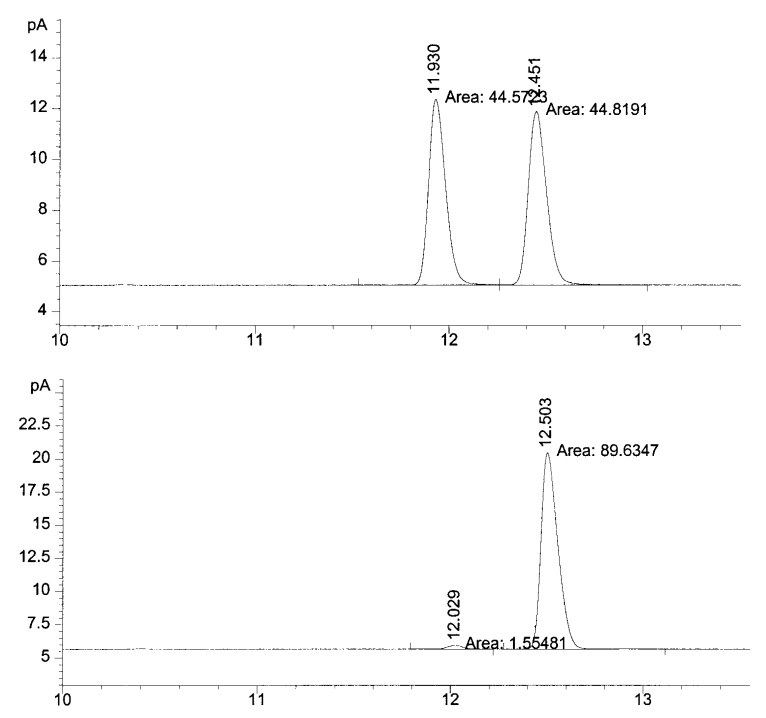

3-(S)-Butylcyclohexanone (Table 2, entry 4): Astec Chiraldex G-TA (30m x 0.25mm x 0.125 $\mu \mathrm{m}$ ) with Astec Retention Gap Guard Column (5m x 0.25mm), $3.4 \mathrm{~mL} / \mathrm{min}$ He flow, $60{ }^{\circ} \mathrm{C}$. This is a known compound. ${ }^{2}$ The absolute configuration was assigned by analogy.<smiles>O=C1CCCC(Br)C1</smiles>

(racemic)

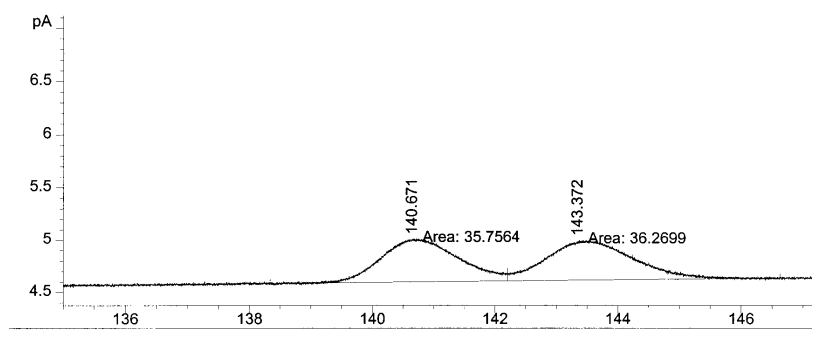<smiles>O=C1CCCC(Br)C1</smiles>

(Table 2, entry 4)

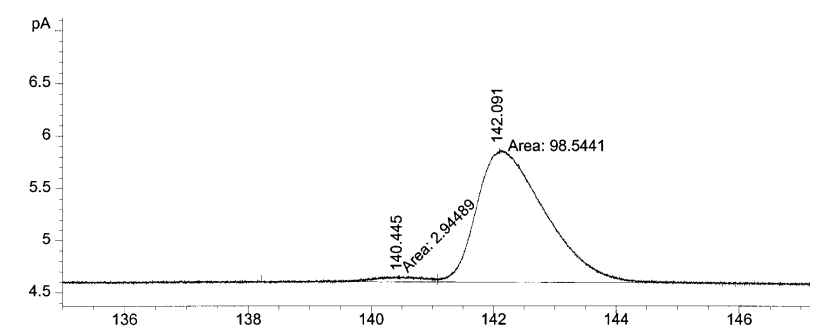

3-(S)-(2'-Methylethyl)-cyclopentanone (Table 2, entry 5): Astec Chiraldex G-TA (30m x 0.25mm x $0.125 \mu \mathrm{m})$ with Astec Retention Gap Guard Column $(5 \mathrm{~m} \times 0.25 \mathrm{~mm}), 1.0 \mathrm{~mL} / \mathrm{min} \mathrm{He}$ flow, $100{ }^{\circ} \mathrm{C}$. This is a known compound. ${ }^{2}$ The absolute configuration was assigned by analogy. 

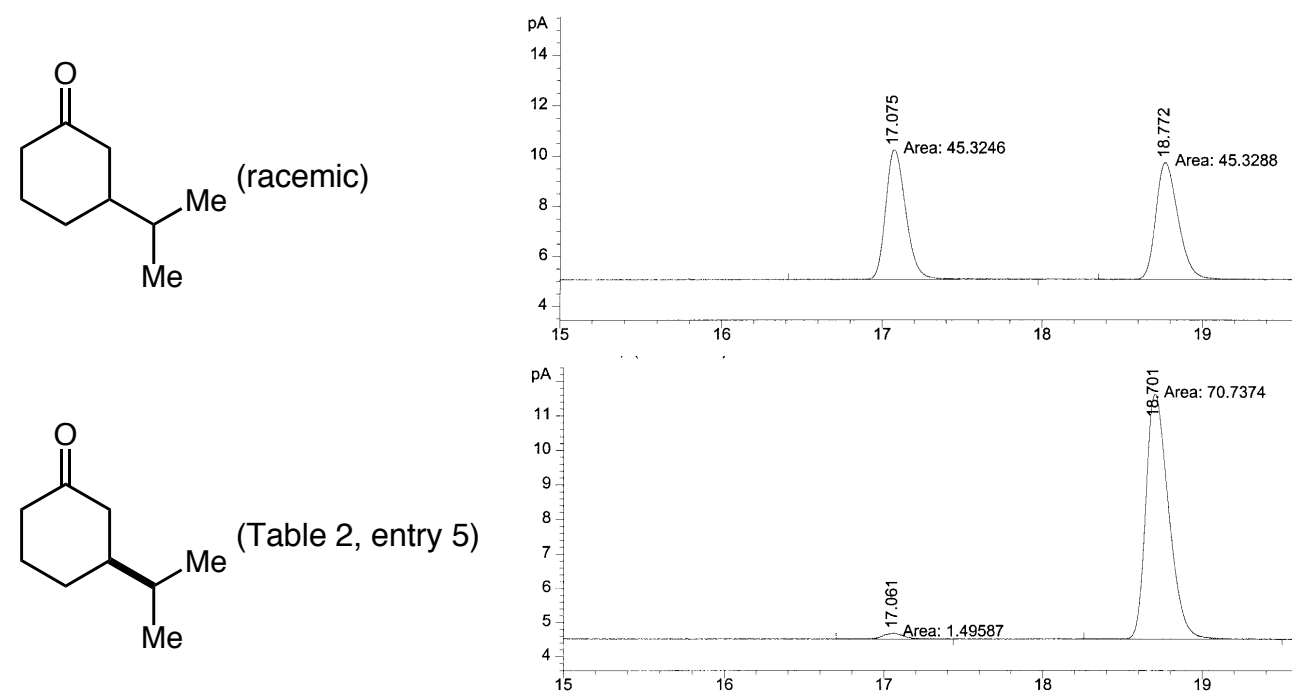

3-(R)-Ethyl-4,4-dimethylcyclopentanone (Table 2, entry 6): Astec Chiraldex G-TA (30m x 0.25mm x $0.125 \mu \mathrm{m})$ with Astec Retention Gap Guard Column $\left(5 \mathrm{~m} \mathrm{x} \mathrm{0.25mm),} 1.0 \mathrm{~mL} / \mathrm{min}\right.$ He flow, $100{ }^{\circ} \mathrm{C}$. This is a known compound. ${ }^{3}$ The absolute configuration was assigned by analogy.<smiles>CCC1CC(=O)CCC1(C)C</smiles>

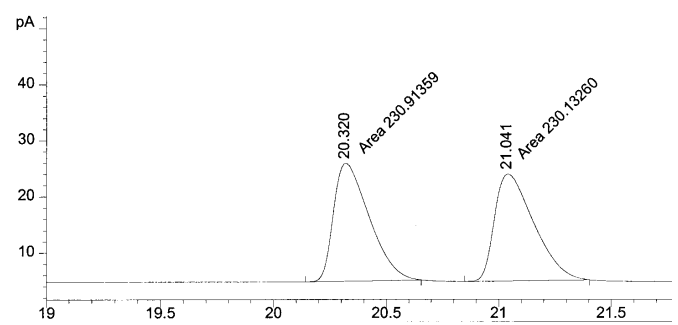<smiles>CC[C@H]1CC(=O)CCC1(C)C</smiles>

(Table 2, entry 6)

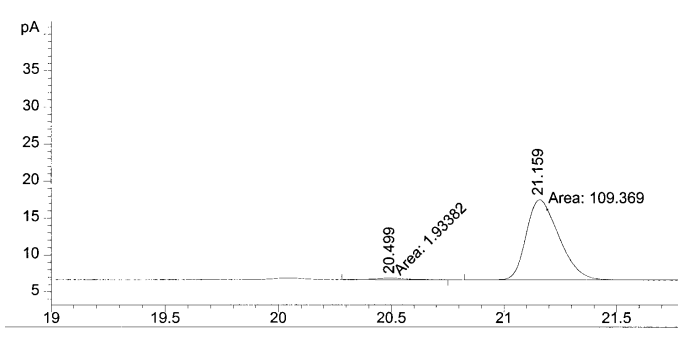

3-(S)-Ethylcycloheptanone (Table 2, entry 7): Astec Chiraldex G-TA (30m x 0.25mm x 0.125 $\mu \mathrm{m}$ ) with Astec Retention Gap Guard Column (5m x 0.25mm), $1.0 \mathrm{~mL} / \mathrm{min}$ He flow, $100{ }^{\circ} \mathrm{C}$. This is a known compound. ${ }^{2}$ The absolute configuration was established by optical rotation: $[\square]_{\mathrm{D}}=-61.7^{\circ}\left(c 1.06, \mathrm{CHCl}_{3}\right)$; lit. $^{2}[\square]_{\mathrm{D}}=+60.4^{\circ}\left(c 1.04, \mathrm{CHCl}_{3}\right)$ for the $R$ enantiomer of $98 \%$ ee.

(3) Feringa, B. L. Acc. Chem. Res. 2000, 33, 346-353. 


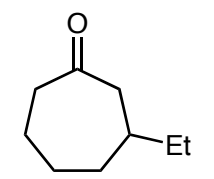

(racemic)
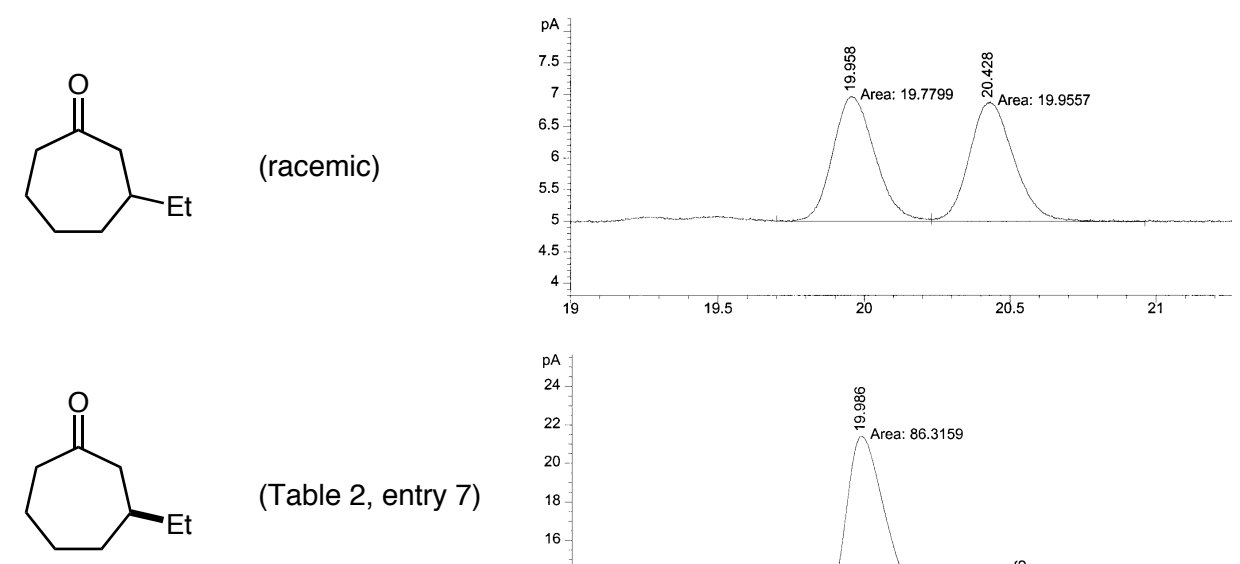

(Table 2, entry 7)

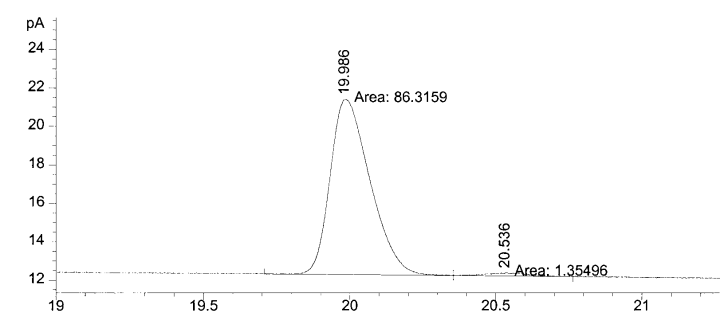

3-(S)-(2'-Methylethyl)-cycloheptanone (Table 2, entry 8): Astec Chiraldex G-TA (30m x 0.25mm x $0.125 \mu \mathrm{m})$ with Astec Retention Gap Guard Column $(5 \mathrm{~m} \times 0.25 \mathrm{~mm}), 1.0 \mathrm{~mL} / \mathrm{min}$ He flow, $100{ }^{\circ} \mathrm{C}$. This is a known compound. ${ }^{2}$ The absolute configuration was assigned by analogy.
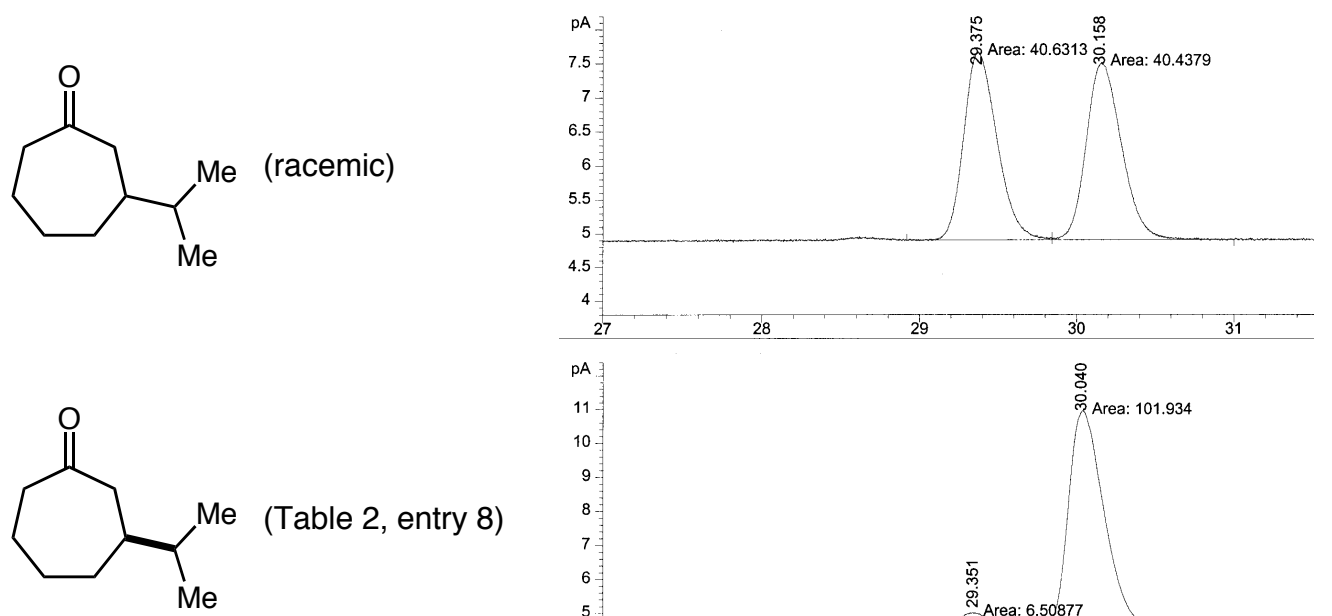

(Table 2, entry 8)

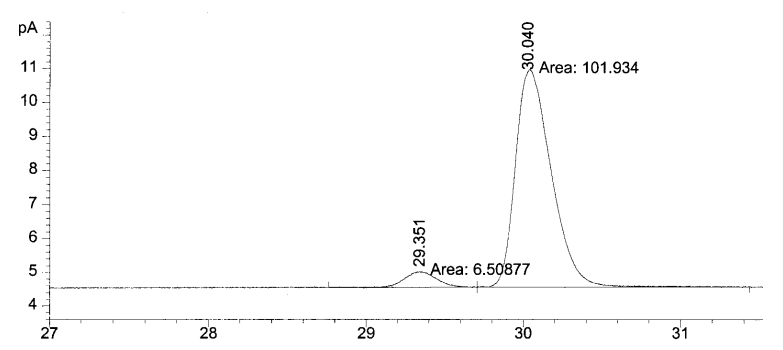


${ }^{1} \mathrm{H}$ NMR (300 MHz, $\mathrm{CDCl}_{3}$ ) spectrum of ligand $\mathbf{2 e}$ :

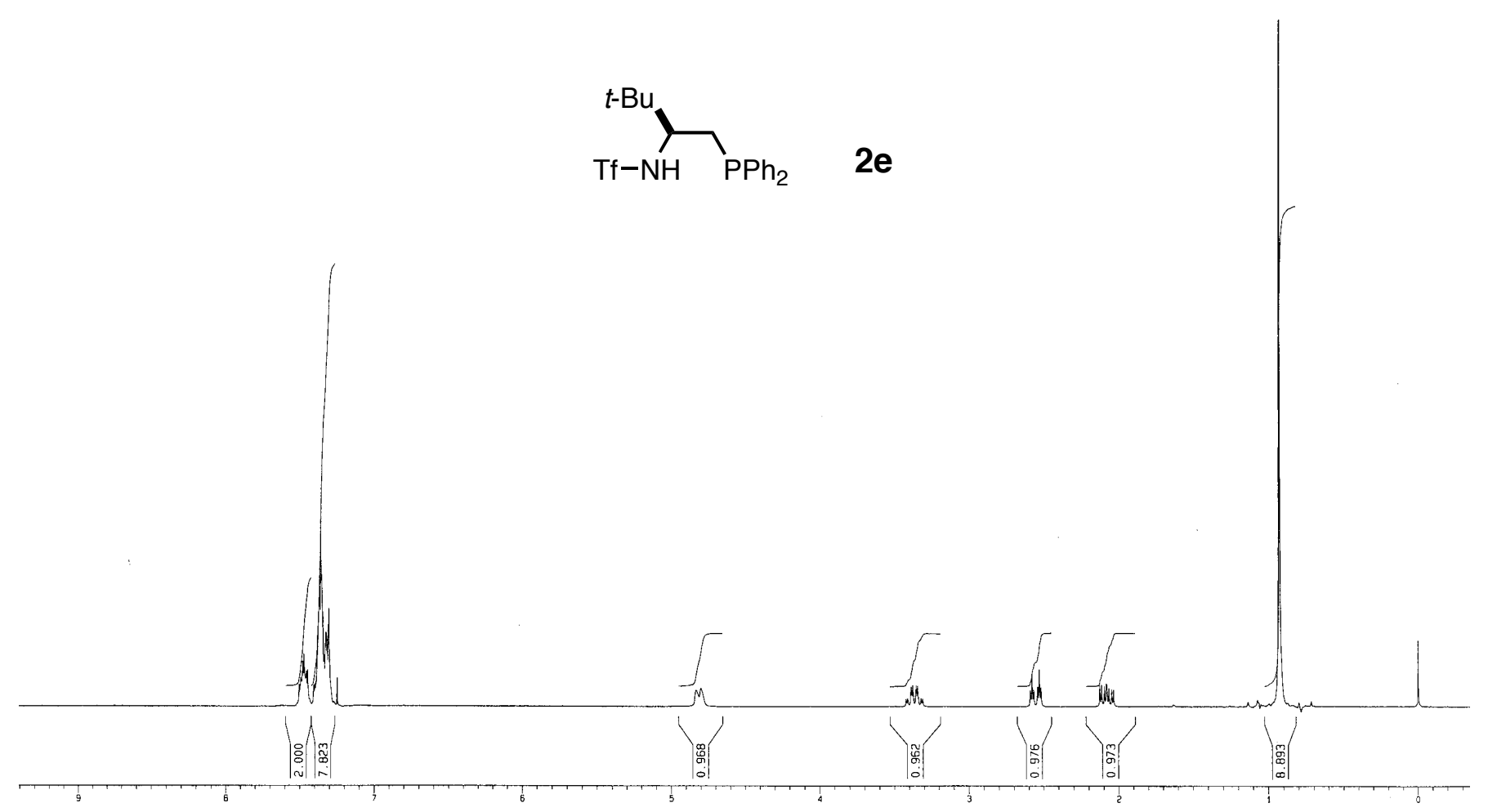

${ }^{1} \mathrm{H}$ NMR (300 MHz, $\mathrm{CDCl}_{3}$ ) spectrum of (1S,5S,7R)-5-Ethyl-8,8-dimethyl-bicyclo[5.1.0]octan-3-one: 


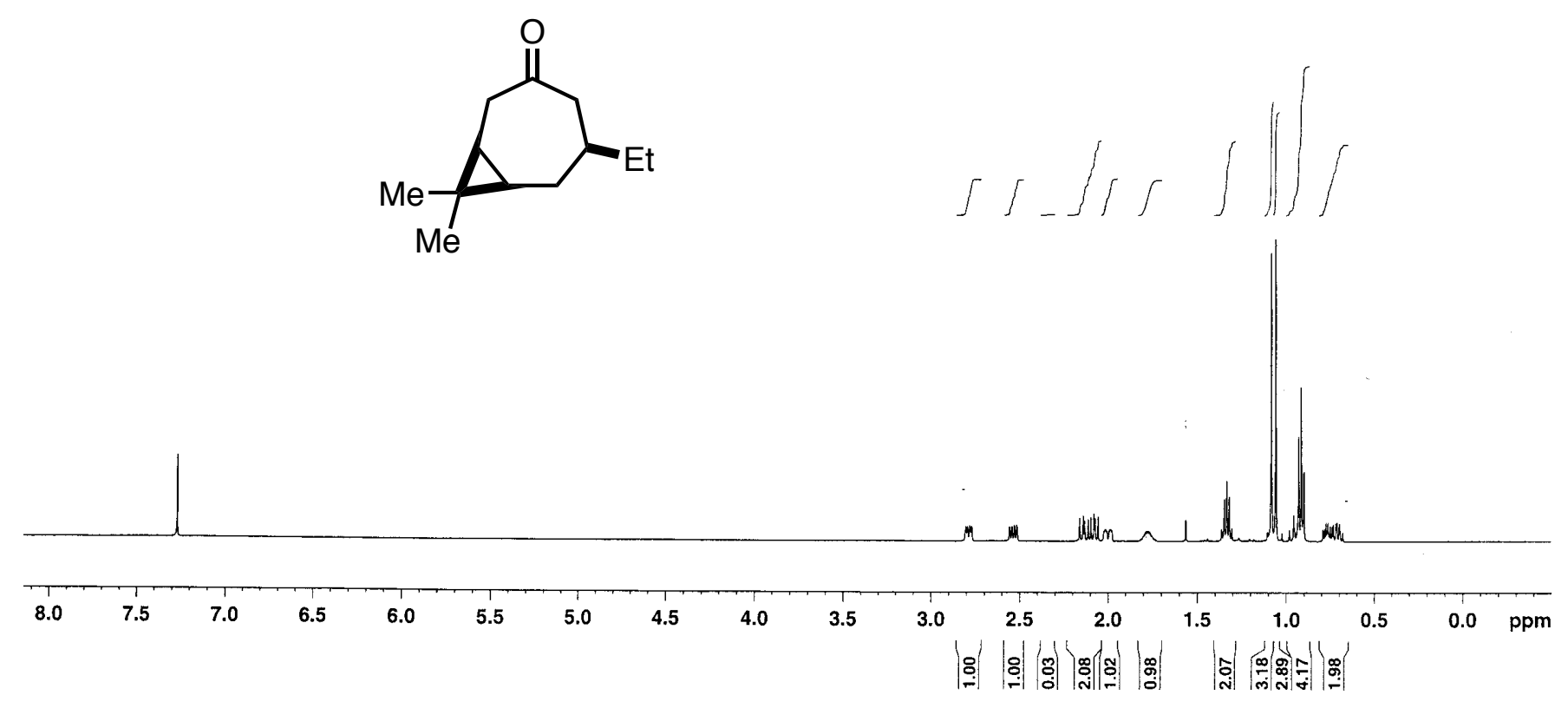

